\title{
CERVICAL RIPENING BALLOON AS A METHOD OF PREINDUCTION - ONE CENTER STUDY
}

\author{
Vesna Košec, Ivka Djaković and Senka Sabolović Rudman
}

Department of Gynecology and Obstetrics, Sestre milosrdnice University Hospital Center, Zagreb, Croatia

\begin{abstract}
SUMMARY - Cervical ripening can be promoted in many ways, but mechanical methods are among the oldest. Like all other methods, this one also has its pros and cons. Disadvantages compared to pharmacological methods include some maternal discomfort upon manipulation of the cervix, a theoretical increase in the risk of maternal and neonatal infection from the introduction of a foreign body, potential disruption of a low-lying placenta, and increase in the need of oxytocin induction of labor. The aim of the study was to evaluate the effect of using cervical ripening balloon in preinduction on the mode of delivery. This was a longitudinal, cohort, intervention, non-randomized one center study. Inclusion criteria were term pregnancies with gestational diabetes, oligohydramnios, intrauterine growth restriction, gestational hypertension/preeclampsia and pregnancies after 41 weeks of pregnancy. Preinduction of labor was performed in term pregnancies at Sestre milosrdnice University Hospital Center. Results in the first 150 women having undergone labor preinduction with cervical ripening balloon were included. Two-sided p values $<0.05$ were considered significant. Statistical analysis was done using SPSS Version 20.0. The study included 150 women; one woman was excluded from further analyses due to conversion of fetal presentation (head to breech). Indications for labor preinduction were as follows: gestational diabetes, oligohydramnios, intrauterine growth restriction, gestational hypertension/preeclampsia and pregnancies after 41 weeks of pregnancy. Women with normal vaginal delivery (96/149) had lower rates of gestational diabetes and oligohydramnios and used epidural analgesia more frequently. Women with dystocia (32/53) had a significantly longer labor duration and higher neonatal birth weight. In multivariate analysis, multiparity, greater cervical dilatation after balloon removal and use of epidural analgesia were associated with a decreased risk of cesarean section, while the presence of gestational diabetes and oligohydramnios was associated with an increased risk of cesarean section. We found this preinduction method safe and efficient, with a potential to increase the rate of vaginal deliveries.
\end{abstract}

Key words: Labor, obstetric; Labor, induced; Cervical ripening; Cervix uteri; Cesarean section

\section{Introduction}

Induction of labor before its spontaneous onset is often necessary in everyday practice. If the indications for labor induction are satisfied, it is not recommended to wait for spontaneous contractions in the best interest of mother and child ${ }^{1,2}$. The most common indica-

Correspondence to: Ivka Djakovic, MD, Department of Gynecology and Obstetrics, Sestre milosrdnice University Hospital Center, Vinogradska c. 29, HR-10000 Zagreb, Croatia

E-mail: ivkadj@yahoo.com

Received October 17, 2018, accepted December 7, 2018 tions for preinduction are gestational diabetes (GDM), oligohydramnios, intrauterine growth restriction (IUGR), pregnancies after 41 weeks of pregnancy and avoidance of unfavorable circumstances such as delivery in the night hours or lack of experienced staff ${ }^{2,3}$. Also, some specific obstetric conditions such as preeclampsia, pregnancy induced or aggravated hypertension, oligohydramnios and cholestasis are reasons for labor induction ${ }^{1}$.

The oldest methods of labor preinduction are mechanical devices. Nowadays, these are replaced by pharmacological agents. However, pharmacological agents have side effects, e.g., tachysystole. They also 
have specific storage requirements, expiration time and higher price ${ }^{4,5}$.

On the other hand, mechanical devices for labor induction are unpleasant, have a higher risk of maternal and neonate infection, as well as the risk of hemorrhage and need for oxytocin. When compared to pharmacological agents, time before onset of contractions is longer. There is no difference in cesarean section (CS) incidence ${ }^{4,5}$.

The aim of our study was to evaluate the effect of using cervical ripening balloon $(\mathrm{CRB})$ in preinduction on the mode of delivery.

\section{Materials and Methods}

We present a longitudinal, cohort, intervention, non-randomized one center study. All women included in the study had the criteria for medical induction and Bishop score under 6. Inclusion criteria were term pregnancies with GDM, oligohydramnios, IUGR, gestational hypertension/preeclampsia, and pregnancies after 41 weeks of pregnancy. We established duration of pregnancy by ultrasound examination in first trimester. Preinduction of labor was performed in term pregnancies at Sestre milosrdnice University Hospital Center.

The Cook Medical ${ }^{\circledR}$ CRB (Bloomington, USA) has been used for labor preinduction at our department. It is a double-balloon catheter guided by stylet during placement. Internal balloon is placed through the cervix in the uterine cavity and filled with $20 \mathrm{~mL}$ of saline, and the external one is outside the cervix, also filled with $20 \mathrm{~mL}$ of saline. The balloons are later enlarged by adding $20 \mathrm{~mL}$ of saline to up to $80 \mathrm{~mL}$ maximum each. After placement of the catheter, there is no need for rest in bed, as is the case in prostaglandin induced labor. The balloon catheter is removed after 12 hours.

We present our experience in 150 patients with cervical balloon preinduction. We analyzed characteristics of the study population according to the mode of delivery and indications for CS, association between the number of comorbidities and presence of dystocia and asphyxia, and difference in birth weight and labor duration between patients with dystocia and asphyxia. Besides objective parameters, we questioned pregnant women about their subjective opinion about this preinduction method.

\section{Statistical analyses}

Patient characteristics were assessed using descriptive statistics, expressed as mean with standard deviation. Continuous variables were compared with oneway analysis of variance (one-way ANOVA) or Kruskal-Wallis test when appropriate. Categorical variables were analyzed using the $\chi^{2}$-test. Logistic regression was used to analyze the link between patient characteristics and the incidence of CS. Backward conditional stepwise approach was used to determine variables independently associated with CS. Regression equation was constructed based on the parameters that were independently associated with CS based on unstandardized correlation coefficients derived from the final step of stepwise conditional backward logistic regression. Receiver operating characteristic (ROC) analysis was performed to determine the sensitivity, specificity, positive and negative likelihood ratio of the regression equation in predicting CS. Two-sided $\mathrm{p}$ values $<0.05$ were considered significant. Statistical analysis was done using SPSS Version 20.0.

\section{Results}

The study included 150 patients; one patient was excluded from further analyses due to conversion of fetal presentation (head to breech). Indications for labor preinduction were as follows: term pregnancies with GDM, oligohydramnios, IUGR, gestational hypertension/preeclampsia and pregnancies after 41 weeks of pregnancy. Characteristics of the study population are shown in Table 1. Patients with normal vaginal delivery (96/149) had lower rates of GDM and oligohydramnios and used epidural analgesia more frequently. CS was performed in 53 patients. Patients with dystocia (32/53) had a significantly longer labor duration and higher neonatal birth weight (Table 1). The number of major comorbidities was significantly higher in patients with dystocia (Fig. 1).

On multivariate analysis, multiparity, greater cervical dilatation after balloon removal and the use of epidural analgesia were associated with a decreased risk of CS, whereas the presence of GDM and oligohydramnios was associated with an increased risk of CS (Table 2).

The following regression equation was constructed: multiparity $\times 2.642$ - dilatation after $\mathrm{CRB} \times 0.338$ epidural analgesia $\times 1.588+$ GDM $\times 0.984$ + oligohy- 
Table 1. Characteristics of study population according to the mode of delivery and indication for cesarean section

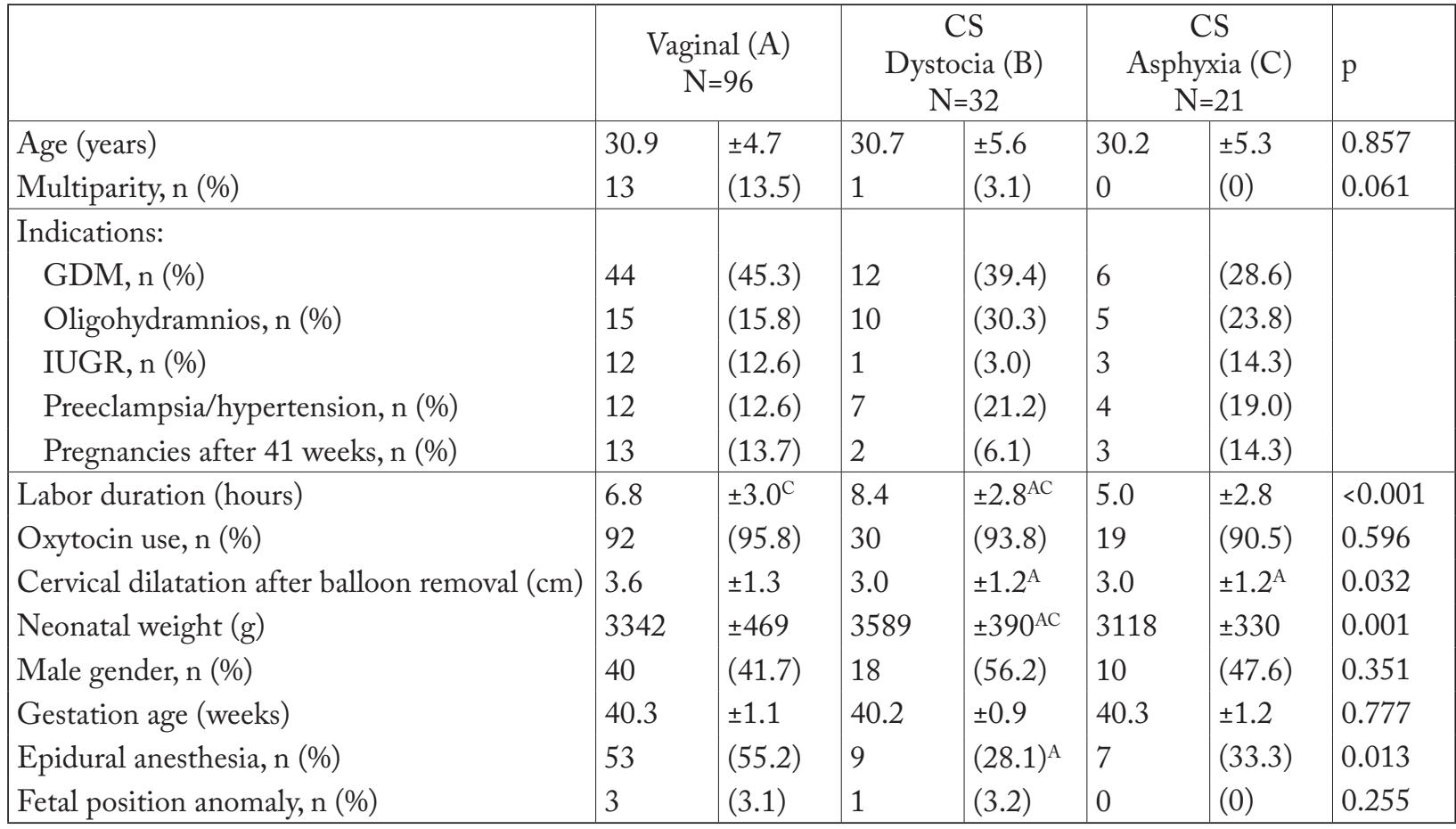

$\mathrm{CS}=$ cesarean section; $\mathrm{A}=\mathrm{p}<0.05$ when compared to vaginal delivery group; $\mathrm{B}=\mathrm{p}<0.05$ when compared to dystocia cesarean section group; $\mathrm{C}=\mathrm{p}<0.05$ when compared to asphyxia cesarean section group; GDM = gestational diabetes; IUGR = intrauterine growth restriction; fetal position anomaly $=$ left occiput or right occiput

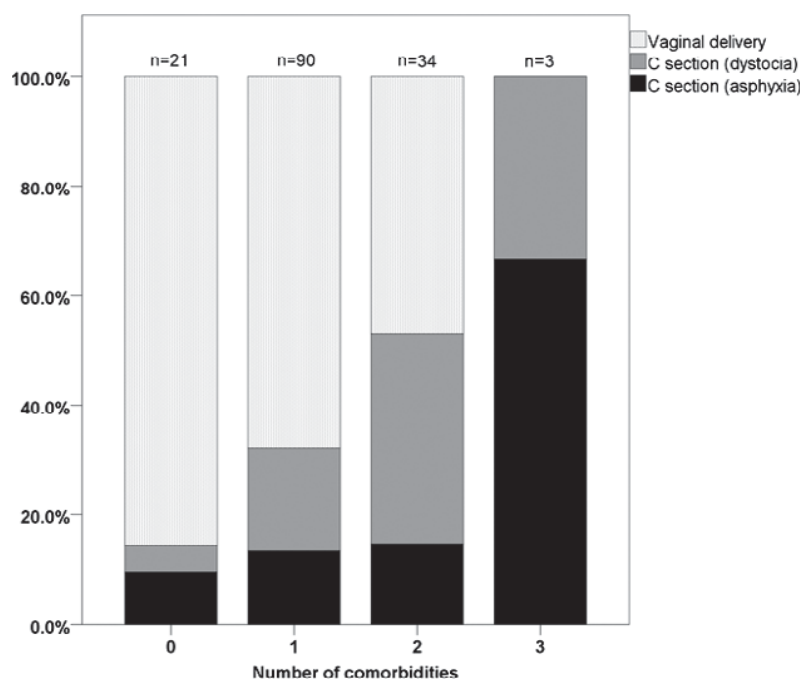

Fig. 1. Histogram showing association between the number of comorbidities and presence of dystocia and asphyxia.

dramnios $\times 1.073$. The equation had $79 \%$ diagnostic accuracy in predicting CS (AUC 0.787, SE 0.039, 95\% CI $0.712-0.863)$. A cut-off $>-1.1025$ best predicted
CS with $71.7 \%$ sensitivity and $75.8 \%$ specificity (Fig. 2).

On multivariate analysis of women who gave birth by CS, asphyxia was associated with shorter labor duration (OR 0.504, 95\% CI 0.311-0.817, p=0.005), greater neonatal birth weight (OR 0.994, 95\% CI 0.990-0.998, $\mathrm{p}=0.004)$ and absence of GDM (OR $0.065,95 \%$ CI 0.006-0.671, $\mathrm{p}=0.022$ ), when compared with dystocia. Difference in neonatal birth weight and labor duration between the two groups is presented in Figure 3.

Out of 150 women, 138 were satisfied with this preinduction method and stated to have a peaceful night without pain. Another 12 women experienced minor discomfort and light pressure in lower abdomen. None of the study women had major objections. None of 150 women and their newborns had infection.

\section{Discussion}

Safety of the mother and the newborn should always come first, knowing the side effects of pharmaco- 
Table 2. Final step of backward conditional stepwise logistic regression showing independent variables associated with the risk of cesarean section

\begin{tabular}{|l|l|l|l|l|l|l|}
\hline & $\mathrm{B}$ & $\mathrm{SE}$ & $\mathrm{HR}$ & \multicolumn{2}{|c|}{$95 \% \mathrm{CI}$} & $\mathrm{p}$ \\
\hline Multiparity & -2.642 & 1.113 & 0.071 & 0.008 & 0.631 & 0.018 \\
Dilatation after CRB & -.338 & 0.170 & 0.713 & 0.510 & 0.996 & 0.047 \\
Epidural anesthesia & -1.588 & 0.417 & 0.204 & 0.090 & 0.462 & 0.000 \\
GDM & 0.984 & 0.414 & 2.674 & 1.189 & 6.017 & 0.017 \\
Oligohydramnios & 1.073 & 0.457 & 2.924 & 1.194 & 7.161 & 0.019 \\
\hline
\end{tabular}

$\mathrm{B}=$ unstandardized correlation coefficient $\mathrm{SE}=$ standard error; $\mathrm{HR}=$ hazard ratio $\mathrm{CRB}=$ cervical ripening balloon; GDM = gestational diabetes mellitus

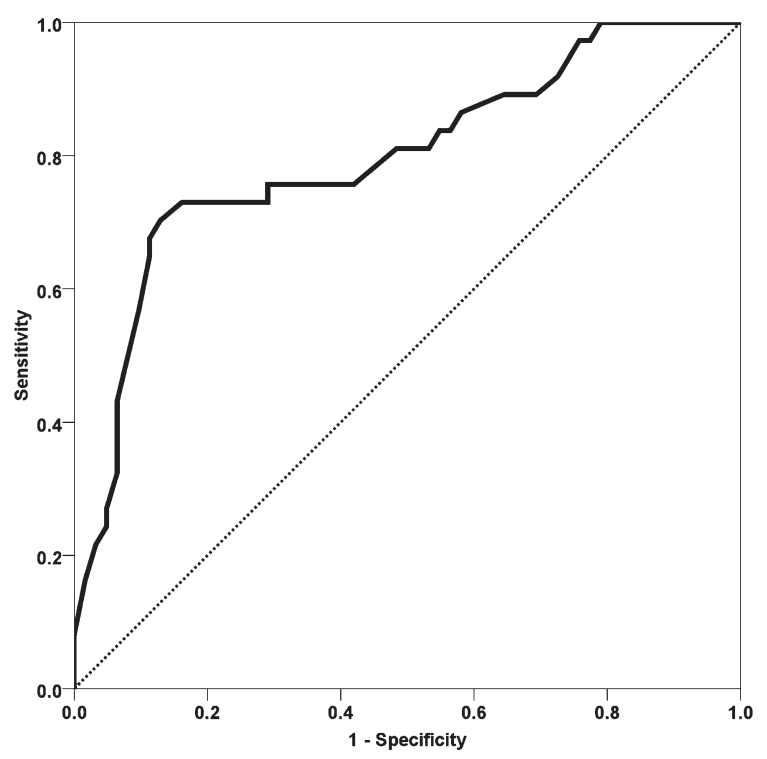

Fig. 2. Receiver operating curve showing diagnostic performance of the regression equation in predicting cesarean section.

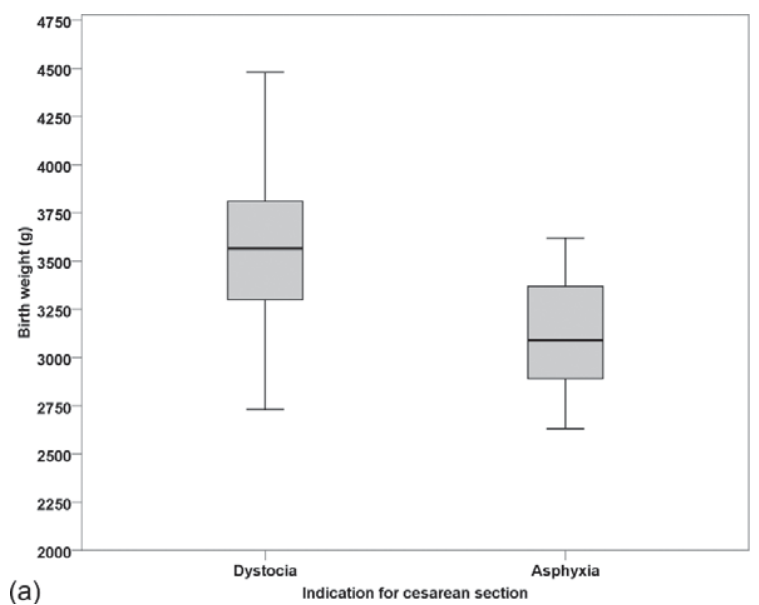

(a) logical agents used for labor induction ${ }^{4,6}$. When CRB is used, mechanical dilatation of the cervix is achieved by gradual increase of the pressure in the balloons. Cervical ripening is achieved by local production of prostaglandins induced by division of the amnion from the decidua, as well as by mechanical dilatation of the cervix ${ }^{7,8}$.

Randomized studies mostly report the same efficiency of labor preinduction with CRB and prostaglandin E2 ${ }^{9,10}$. Brown and Beckmann found a higher number of vaginal deliveries, less fetal acidosis, less blood loss, and more subjective satisfaction in the CRB group compared with prostaglandin E2 group 9 . Lim et al. recorded the same level of subjective satisfaction in both groups but the intensity of pain was lower in the CRB group ${ }^{10}$.

Even more interesting are studies of $\mathrm{CRB}$ labor preinduction in women with previous $\mathrm{CS}^{11,12}$, concluding that this preinduction method is safe and effective $^{11}$. Over $50 \%$ of pregnant women had successful

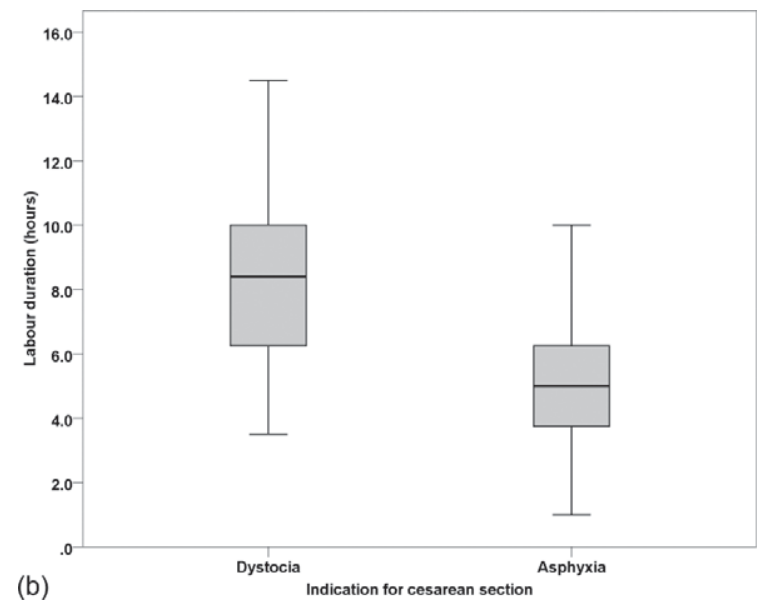

Fig. 3. Birth weight and labor duration were independently associated with the presence of dystocia and asphyxia.

Box plot charts show difference in birth weight (a) and labor duration (b) between patients with dystocia and asphyxia. 
vaginal delivery. The rate of intrapartal CS scar rupture was $1.2 \%$ and did not differ from the group with CS scar $^{11}$. Radan et al. report the same safety of CRB and oxytocin but found significantly less successful vaginal deliveries in CRB group women with CS scar. The groups were not comparable due to inclusion of different Bishop scores at the beginning of the study ${ }^{13}$. Sharma et al. conducted a randomized study comparing oral administration of prostaglandin E1 and CRB in women with prior $\mathrm{CS}^{14}$. They also found significantly less successful induction in $\mathrm{CRB}$ group and higher need for oxytocin. There was no difference in the mode of delivery between the groups ${ }^{14}$.

In our study, we put more accent on group characteristics than on method efficiency, since these data are already widely available in the literature. We analyzed the course and mode of delivery in cases with medical indications for labor induction in pregnant women with immature cervix (Bishop score under 6) ${ }^{15}$. Prostaglandins may be risky in these cases and most of the women would be candidates for elective CS without CRB labor preinduction. However, two-thirds of the women in our study had successful vaginal delivery. In the group that had CS, dystocia was indication for CS in 32/149 and asphyxia in 21/149 women. Specific risk factors for CS are labor duration and weight of the newborn. The risks connected with dystocia are prolonged labor duration and higher weight of the newborn.

Advantages of this technique include lower cost compared with some drugs, low risk of tachysystole, few systemic side effects, and convenient storage requirements (no refrigeration or expiration, which are issues for some drugs $)^{4,5,16}$.

In conclusion, we found this preinduction method safe, efficient, and offering potential to increase the rate of vaginal deliveries in pregnant women with medical indication for induction.

\section{References}

1. Rozenberg P. In case of fetal macrosomia, the best strategy is the induction of labor at 38 weeks of gestation. J Gynecol Obstet Biol Reprod (Paris). 2016. pii: S0368-2315(16)30102-8. (In French) http://dx.doi.org/ 10.1016/j.jgyn.2016.09.001.

2. Boulvain M, Irion O, Dowswell T, Thornton JG. Induction of labour at or near term for suspected fetal macrosomia. Cochrane Database Syst Rev. 2016;(5):CD000938. http://dx.doi. org/ 10.1002/14651858.CD000938.pub2
3. Rydahl E, Eriksen L, Juhl M. Effects of induction of labor prior to post-term in low-risk pregnancies: a systematic review. JBI Database System Rev Implement Rep. 2018 Oct 5. http:// dx.doi.org/10.11124/JBISRIR-2017-003587. [Epub ahead of print]

4. Du YM, Zhu LY, Cui LN, Jin BH, Ou JL. Double-balloon catheter versus prostaglandin E2 for cervical ripening and labour induction: a systematic review and meta-analysis of randomised controlled trials. BJOG. 2016 Aug 17. [Epub ahead of print]. http://dx.doi.org/ 10.1111/1471-0528.14256

5. Alfirevic Z, Keeney E, Dowswell T, Welton NJ, Medley N, Dias S. Methods to induce labour: a systematic review, network meta-analysis and cost-effectiveness analysis. BJOG. 2016;123 (9):1462-70. http://dx.doi.org/ 10.1111/1471-0528.13981

6. Vogel J, Osoti AO, Kelly AJ, Livio S, Norman JE, Alfirevic Z. Pharmacological and mechanical interventions for labour induction in outpatient settings. Cochrane Database Syst Rev. 2017;9:CD007701.

http://dx.doi.org/ 10.1002/14651858.CD007701.pub3

7. Teo EY, Kumar S. Intrapartum intervention rates and perinatal outcomes following induction of labour after $41+0$ weeks compared to expectant management. J Matern Fetal Neonatal Med. 2017;30(21):2517-20. http://dx.doi.org/10.1080/14767058.20 16.1255190

8. Menon R. Human fetal membranes at term: dead tissue or signalers of parturition? Placenta. 2016;44:1-5. http://dx.doi.org/ 10.1016/j.placenta.2016.05.013

9. Brown J, Beckmann M. Induction of labour using balloon catheter and prostaglandin gel. Aust N Z J Obstet Gynaecol. 2017;57(1):68-73. http://dx.doi.org/ 10.1111/ajo.12577

10. Lim SE, Tan TL, Ng GYH, Tagore S, Kyaw EEP, Yeo GSH. Patient satisfaction with the cervical ripening balloon as a method for induction of labour: a randomised controlled trial. Singapore Med J. 2018;59(8):419-24. http://dx.doi.org/ 10.11622/smedj.2018097

11. De Bonrostro Torralba C, Tejero Cabrejas EL, Marti Gamboa S, Lapresta Moros M, Campillos Maza JM, Castan Mateo S. Double-balloon catheter for induction of labour in women with a previous cesarean section, could it be the best choice? Arch Gynecol Obstet 2017;2955:1135-43. http://dx.doi.org/10.1007/s00404-017-4343-7

12. Kehl S, Weiss C, Rath W. Balloon catheters for induction of labor at term after previous cesarean section: a systematic review. Eur J Obstet Gynecol Reprod Biol 2016;204:44-50. http://dx.doi.org/ 10.1016/j.ejogrb.2016.07.505

13. Radan AP, Amylidi-Mohr S, Mosimann B, Simillion C, Raio L, Mueller M, Surbek D. Safety and effectiveness of labour induction after caesarean section using balloon catheter or oxytocin. Swiss Med Wkly. 2017;147:w14532.

http://dx.doi.org/10.4414/smw.2017.14532. eCollection 2017

14. Sharma C, Soni A, Gupta A, Verma A, Verma S. Mifepristone vs balloon catheter for labor induction in previous cesarean: a randomized controlled trial. Arch Gynecol Obstet. 2017; 296(2):241-8. http://dx.doi.org/10.1007/s00404-017-4431-8 
15. Ezebialu IU, Eke AC, Eleje GU, Nwachukwu CE. Methods for assessing pre-induction cervical ripening. Cochrane Database Syst Rev. 2015 Jun 12;(6):CD010762. http://dx.doi.org/ 10.1002/14651858.CD010762.pub2
16. Durie D, Lawal A, Zegelbone P. Other mechanical methods for pre-induction cervical ripening. Semin Perinatol. 2015;396:444-9.

http://dx.doi.org/10.1053/j.semperi.2015.07.006

Sažetak

\section{BALON ZA SAZRIJEVANJE CERVIKSA MATERNICE U PREDINDUKCIJI POROĐAJA - JEDNOCENTRIČNA STUDIJA}

\section{Košec, I. Djaković i S. Sabolović Rudman}

Sazrijevanje cerviksa maternice može se poticati na nekoliko načina. Najstarije metode su mehaničke metode koje imaju svojih prednosti i nedostataka. Nedostaci u usporedbi s farmakološkim metodama uključuju određenu majčinsku nelagodu pri manipulaciji cerviksom maternice, povećanje rizika od majčine i neonatalne infekcije zbog unošenja stranog tijela, mogućnost ozljede posteljice niskog sijela i povećanu potrebu za uporabom oksitocina u porođaju. Cilj istraživanja bio je procijeniti učinak korištenja balona na sazrijevanje cerviksa maternice u predindukciji porođaja. Provedena je longitudinalna, kohortna, intervencijska, ne-randomizirana studija. Kriteriji za uključivanje bili su terminske trudnoće s gestacijskim dijabetesom, oligohidramnijem, intrauterinim zastojem u fetalnom rastu, gestacijskom hipertenzijom/preeklampsijom i trudnoća nakon navršenih 41 tjedna trudnoće. Studiju smo provodili kod žena s terminskim trudnoćama u Kliničkom bolničkom centru Sestara milosrdnica. Prikazani su rezultati u prvih 150 trudnica kod kojih je provedena predindukcija porođaja cervikalnim balonom. Vrijednosti p<0,05 smatrale su se značajnima. Statistička analiza provedena je pomoću SPSS Version 20.0. Studija je obuhvatila 150 trudnica, a jedna žena je bila isključena iz daljnjih analiza zbog konverzije fetalnog stava (glave u zadak). Indikacije za predindukciju porođaja su bile: gestacijski dijabetes, oligohidramnij, intrauterini zastoj fetalnog rasta, gestacijska hipertenzija/preeklampsija i trudnoća nakon navršenih 41 tjedna trudnoće. Trudnice koje su rodile vaginalno (96/149) imale su manju učestalost gestacijskog dijabetesa i oligohidramnija i kod njih je češće korištena epiduralna analgezija. Trudnice bez napredovanja porođaja (32/53) imale su značajno duže trajanje porođaja i veću tjelesnu težinu novorođenčeta. U multivarijatnoj analizi su multiparitet, veća dilatacija cerviksa nakon uklanjanja balona i primjena epiduralne analgezije bili povezani sa smanjenim rizikom carskog reza, dok je prisutnost gestacijskog dijabetesa i oligohidramnija bila povezana s povećanim rizikom carskog reza. Smatramo da je ova predindukcijska metoda sigurna, učinkovita i može dovesti do povećanja broja vaginalnih porođaja.

Ključne riječi: Porođaj; Porođaj, inducirani; Cerviks, sazrijevanje; Cerviks uterusa; Carski rez 